\title{
Row Sport Context in PISA Like Mathematics Problem
}

\author{
Arvin Efriani, Ratu Ilma Indra Putri, Hapizah \\ Sriwijaya University, Jl. Srijaya Negara, Bukit Besar, Palembang, Indonesia
}

\begin{tabular}{l} 
Article Info \\
\hline Article history: \\
Received Feb 27, 2018 \\
Revised Apr 21, 2018 \\
Accepted Jun 1, 2018 \\
\hline Keywords: \\
Design research \\
Mathematics literacy \\
PISA \\
Row sport
\end{tabular}

\begin{abstract}
The aim of research was to produce valid, practical and had potential-effect to mathematic literacy ability in PISA like mathematics problem in using row sports context at Asian Games 2018. The research method used development research with development studies type. The subjects of the research were the students with 15 years old of class X SMAN 10 Palembang. The techniques of collecting data were used documentation, walkthrough, test, and interview. This research produced the problem about how the students determined how many benches could be made by only knowing length and width of the boats. The results showed that the problem developed (1) valid from the suitability with the framework PISA regarding content, context, literacy process and level of questions that was connected problems with daily life accordance experts review and one to one stage (2) practical because the problem could be understood by students accordance small group stage, and (3) had a potential effect from the result of analyze the student's answer in mathematical literacy ability with representation and reasoning ability as dominant accordance field test stage.
\end{abstract}

Copyright () 2018 Institute of Advanced Engineering and Science. All rights reserved.

\section{Corresponding Author:}

Ratu Ilma Indra Putri,

Mathematics Education, Sriwijaya University, Palembang.

Email: ratuilma@yahoo.com,

\section{INTRODUCTION}

The goal of curriculum change in 2013 is to get the learning of students that is in line with those tested at the international level [1]. The way to reflect changing of curriculum goals and objectives is by participating in PISA (Program International Student Assessment) [2]. PISA is an international study which is conducted every 3 years to see the literacy ability of 15 -years old students in terms of reading, math, science, and finance [3].

Literacy ability is an important ability in the student development process, therefore the ability becomes one of the indicators of the development of the student's ability to improve their performance. One of the literacy ability tested is mathematical literacy. According to Sturgeon [4], using literacy ability to present mathematical concepts can add to the mathematical mindset of students and teachers. After 6th time participating in PISA study, Indonesia always occupied the lowest position. In 2015, the ability of Indonesian student's mathematics literacy was ranked 63 out of 70 countries which were attending with 386 scores. The score is still far below from the international average score of 500 [3].

Mathematical literacy consists of 4 contents, one of them is space and shape. The question of shape and space content is related to the ability to apply concepts, facts, procedures and mathematical reasoning related to the shape and space of geometry in daily life [5]. Space and shape content is the basis of geometry. Geometry is a branch of mathematics that contains the properties of lines, angles, planes, and spaces. This content has been introduced from the elementary up to the middle school level. This is in the opinion of Jane [6], "Geometry touches on every aspect of our lives". It is important to explore the shapes, lines, angles, and space that are woven into our students' daily lives as well as our own ". However, in solving space and shape problem, the students still difficult to find the solution proven by the results of PISA who only get a score of 383 from an average score of 500 [7]. This is caused by the delivery of materials and the level of the student's 
ability to receive the material given because the concept of geometry is not only transferred in the form of information but is constructed through their initial knowledge [8], [9]. According to Stacey [10], Indonesian students are only able to answer the problems in the low category and very few even almost no one can answer the problem that demand high-level thinking. Similarly, Djahuno [11] also pointed out that the usual problems were given by teachers in learning emphasize more on routine questions in textbooks which is when examined, are only looking for one true convergent answer. Supposedly, the problems that is given to students can also be divergent problems that make students to analyze, explain, and make guesses, not just solve, find, or count. The problem is like a matter that is tested in international standards that is about PISA with level 3-6.

The low PISA result of Indonesian students is also due to the unfamiliarity of students practice with contextual problem because the PISA problem is not only divergent for high level but also related to the context. This is in accordance with the results of Wijaya's research [12] that Indonesian students are not accustomed to solve problems with the context. So, students have difficulty when convert the problem into a mathematical sentence. In addition, the existence of PISA problem is still related to the context of foreign-life where the context is still foreign to Indonesian students [13]. For training and improving the ability of mathematics literacy with the approach of learning in accordance with the objectives of the curriculum 2013 is the realistic mathematical education (RME), whose mathematics should be closed to the students and relevant to the daily life situation of the students. The situation is not only limited to visible views but also can be imagined and closed to students [14]. The close situation of the student is applied in the form of a problem. Problems which are used in the process of learning mathematics according to the function of education are the problems that potentially develop the ability of mathematical literacy [15], [16].

Contextual problems which can be applied in learning are by giving a question. By solving mathematical problems are using context can help students used mathematical-ability in daily life [17]. According to Barezi [18], giving questions can be a PISA problem which is by giving the problem as early as possible or at the beginning of the students stepped on the middle school level. Zulkardi recommends for designing the PISA problem and use it in the practice of mathematics learning in the classroom [19]. Not only during the learning process in the classroom, but also the problem can be given as homework [20]. Therefore, the questions are given to students for learning in the classroom or as homework should be developed by the teacher in accordance with the context around students.

The context is used in the PISA problem that one of them is related to sports. However, the question of using the sports context is still few. Therefore, this study uses the context of the sport in Asian Games 2018. The Asian Games is a sports competition event held every four years with athletes from all over Asia enrolled in the Olympic Council of Asia (OCA) membership. Jakarta and Palembang will be the host of Asian Games 2018 after Asian Games 1962. Organizing in Palembang, there are only 12 sports that will be competed. One of them is rowing sports. Rowing is a sport that is using a boat that can be played in rivers, lakes, seas and using energy to move it. So, there is an interaction between people and tools that is used. In addition, the rowing sport is an excellent sport to collect medals in Asian Games 2018. By using sports as developed context problems will make students prefer math and also remember the celebration of Asian Games 2018 [21]. Therefore, this article discusses the mathematical literacy ability students which can be trained with the problems developed with the sports context in Asian Games 2018 especially rowing.

\section{RESEARCH METHOD}

This research is the development research with formative evaluation research type [22]. This research consists of two stages, preliminary and prototyping which are included self evaluation, expert review, one to one, small group and field test [22], [23].

The first stage, preliminary, the researcher performs the students analysis, curriculum analysis and PISA analysis as the basis for developing the problem. Furthermore, researcher designs the initial draft of the problem which is developed as well as make the instrument development tools question.

The second stage, prototyping, is which began with self evaluation stage. At this stage, the researcher reviewed and evaluated the initial draft of the question devices that had been designed to produce prototype 1 . Furthermore, prototype 1 was piloted at the expert reviews stage and one to one in parallel.

At the expert reviews stage, prototype 1 is validated in context, construct and language by using walkthrough experts from inside and outside the country. Validation process can be done through three ways: face to face review, mails review, and focus group [22]. While expert review, one to one is done with three students who have various capabilities. One to one focused on the clarity, ease of the using, the practicality of the developed prototype and the students' interest in the given problem. The results of the revision of expert reviews and one to one produce prototype 2 which will be tested in the next stage is small group. 
The small group stage was conducted with six students with various capabilities. After working on prototype 2, then it is done a direct interview to explore the students' comments and suggestions to know the practicality of the problems. The revision result of the questions based on the comments and suggestions of the students at the small group stage. So, that will produce prototype 3 tested in the field test stage. In the field test stage, prototype 3 was tested on the subject of the study of the students of class X MIA 1 SMA Negeri 10 Palembang which are consisted of 32 students. Data collection techniques are used (1) documentation, (2) walk-through, (3) test and (4) interview. Data was analyzed descriptively from expert reviews comments, one to one, student answers and interviews.

\section{RESULTS AND ANALYSIS}

This research results PISA like mathematics problem with rowing context. The process of problem development has been passed with prelimenary and prototyping [22], [23]. The preliminary stage is analyze the students that is 15 years old student who will be subject of research and analyze the curriculum which is in accordance with Indonesian curriculum that is curriculum 2013 by applying PISA problem in learning. In the preliminary stage was chosen by the research subjects is student in SMA N 10 Palembang which is 15 years old, the content is space and shape because it can be linked with the rowing boat context then researchers collected the PISA questions Furthermore, researchers make a problem with the reference of PISA problems that is existed and has been developed. The question of reference and problem developed is shown in Figure 1.

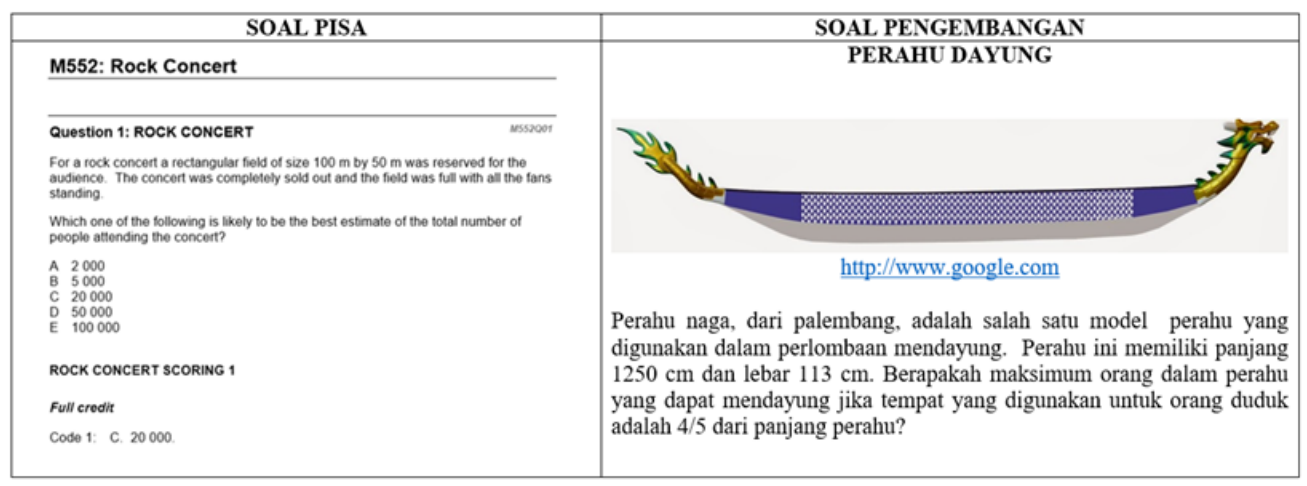

Figure 1. Problem of PISA and Problem developed

From Figure 1, the reference of issue is a problem a PISA in 2006. The problem determines how many people can stand in a concert field measuring $100 \mathrm{~m}$ x $50 \mathrm{~m}$. Then, the researcher makes paraphrased by changing the image and reformulating the problem into different aspects adopted from the Bairac method [24]. This question determines how many people can sit in a rowboat measuring $1250 \mathrm{~cm} \mathrm{x} 113 \mathrm{~cm}$. The size of the boat that is used according to the actual size of the boat. The using of a row context due to the row is a part of the aquatic sports that contribute a lot of medals in every races. So that, it becomes a mainstay sport Asian Games 2018 because of the achievements that they have achieved. In addition, the rowing branch at the Asian Games 2018 will be held in Palembang City so that this sport is known to students, especially students in Palembang city.

The next is the prelimenary stage. In this stage, it is begun by self evaluation which researcher evaluated and examined her own draft about the like of PISA. Problems have been developed that are the problems with the context of the rowing sports. Context on this problem belongs to the personal context and its content is space and shape, especially, the using of surface area. The mathematical process that occured in the solution is an interpretation. The level prediction of this problem is level 6 . It is according to the characteristics of the PISA level 6 problem are shown from the problem of conceptualizing, generalizing, using information and putting it into a complex situation. In addition, students can apply their deep understanding along with mathematical operations, connect information sources to solve problems and evaluate appropriates problem-solving strategies when deal with complex situations. Developed problem that is from the results of self-evaluation is in accordance with the PISA framework so that there is no revision. Problems that have been developed at this stage are called prototype I. Next, prototype I is validated by expert reviews and one to one in parallel. 
Validation of prototype 1 is done qualitatively in terms of contents, constructions and languages. The problem device is consulted to experts who have experienced in PISA as validator. The prototype 1 validation process is done through two ways: mail review and focus group. Experts who act as validators on mail reviews are (1) Ross Turner (E1) as director of the Australian Council for Educational Research (ACER), Team MEG PISA, (2) Kaye Stacey (E2) as Chairman of MEG PISA from University of Melbourne, Australia and (3) Ahmad Fauzan (E3) is a lecturer in mathematics State University of Padang. While the validation of focus group is done directly by the researchers along with some students and lecturers. The lecturers are Zulkardi (E4) and Somakim (E5). Also, there is one student who focuses on the researcher, is Dedi Yansen (E6) he discussed the overall problem in terms of contents, constructions and languages. Along with the expert reviews stage, researcher also performed one to one stage. The following comments and suggestions from experts and students are presented in Table 1.

Table 1. Comments and Suggestions of Expert and One to One

\begin{tabular}{ll}
\hline Code & \multicolumn{1}{c}{ Comments and Suggestions } \\
\hline E1 & The question is very closed and given closed answer. But I think there are many ways to do \\
the modeling and difference answers can be happened in modeling in this situation. The \\
alternative is boat builders who want to know how many seats will fit in the boat. The \\
emphasize is how students model the space are needed by two rowers to sit side by side. \\
Please, used PISA's rubric and for indicators adjust to the correct answer. \\
Are there two people in a row? The solutions and problems are good but you have to give \\
support to the students to know the solution what you want. \\
E2 \\
Spaces on the problem are fixed and the using of more precise words for 'rowing' or 'rowing \\
boats' \\
The problems are maintained but are developed again so that they become two questions \\
O1 $\begin{array}{l}\text { It should be the image is added from the top view. } \\
\text { Keep the information of straight or folded sitting. }\end{array}$
\end{tabular}

This comment is as consideration to revise prototype I. Based on the validation process at the expert reviews and one to one stage, the problem is maintained with several revisions such (1) clarifying information by adding the image from the top view and by adding information about how many rower can sit in one line, (2) changing the rubric assessment to rubric assesment in PISA, (3) adjusting the indicator by step doing. For advice from E4 to keep the question which is not accepted because of having to choose one of the problems. Thus, in PISA question is not related and advice from students to add the seat area information for one person. Meanwhile, it is not accepted because it will change the level prediction and not in accordance with the framework PISA. After revision, the problem becomes as shown as in Figure 2. The result of this revision is called prototype 2 .

PERAHU DAYUNG

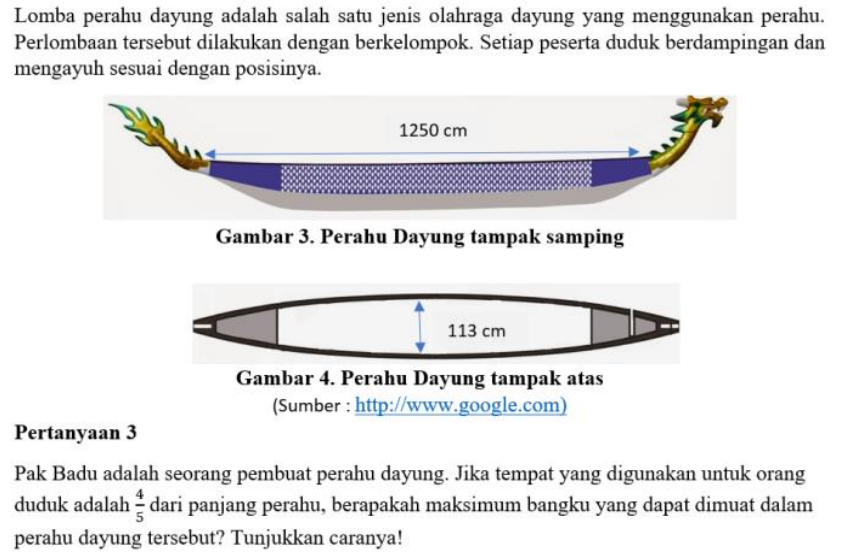

Figure 2. Prototype 2 
Furthermore, the problem of prototype 2 was tested in small group. Small group process was done on November 7, 2017. In small group stage, students are given the problem to be done individually. During the process of the problem, the high and middle ability students have already understood the purpose of the problem by writing the problem in mathematics problem with known and unkown problem while the low ability student do not try to do the problem. After trying to find the solution, students could be confused how to do the problem. However, students are still trying to write down the answers by dividing the length of the boat with its width so that directly get answers without a logical reason. After that, the students formed a small group to discuss the problem. In small groups, students determine solutions based on the answers as individually. The high student ability explain the purpose of possible answers by assuming they are sitting in a boat. However, students are confused about how to write down the answers. So the researchers suggest what is orally expressed by the student to be written. However, students are still hesitant to write down the answers. At this stage, the researcher did not revise the problem because the tested problem was well understood by the students and the pictures were used clear and support the question. The results of this stage is practical problems.

The next stage is the field test which was held on November 9th 2017. One of the objectives of the field test is to know the potential effect of the problem on the students' mathematical literacy ability. After the students have finished the problem, the researcher interviewed the students to explore the potential effects of the problems that have been developed.

Solving the problems that have been developed can be done by choosing in advance the length of the boat that can be used to sit. By knowing the length and width of the boat, the students can determine which bench can be made by estimating. The distance of each bench can be made to know the maximum number of benches that can be made. From the mathematical abilities involved, the students need the ability of using language and symbolic, formal and technical to make the relation between the context and the provided representation. Also, the students need the ability to choose strategies to solve problems. Furthermore, students also need the ability of mathematize by determining the boundaries of the exist problems. After getting a solution, the students can use their reason and arguments abilities in reflecting on the solution. Except that, make explanations and reasons that support or deny the problem. Once the problem is resolved, the students can communicate the explanation and argumentation of problem solution. Here is the correct student's answer as shown as Figure 3.

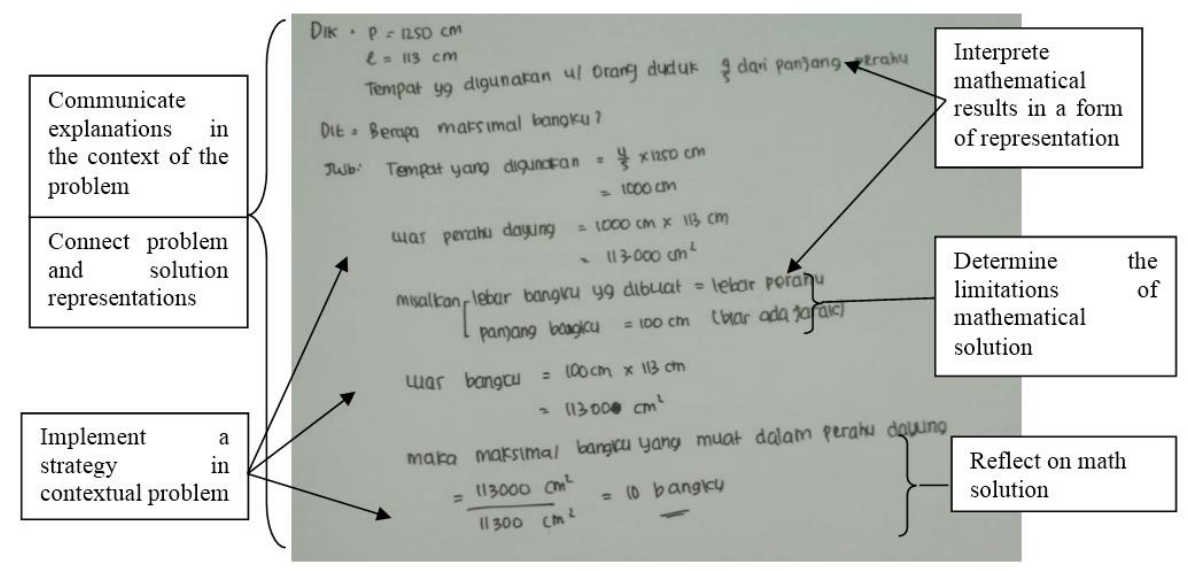

Figure 3. Correct Student's answer

For the student answer as shown in Figure 3, the student has already understood the meaning of the problem well and solved the problem correctly. The student can apply a strategy of determining the maximum number of benches that can be made by calculating the area of the boat and counting a bench is used for sitting. In determining the limitations of mathematical solution, the student only specify the lengths for each bench in $100 \mathrm{~cm}$. Therefore, the student has not been able to make a denying statement from the solution. In addition, the student can interprete mathematical results in verbal representation such as determining where seats can be made, namely $4 / 5$ of the length of the boat and stating the mathematical solution but do not give the meaning to the solution. Then, the student can communicate explanations and arguments in the context of the problem but it has not yet complete because there are unclear explanations such as "has a distance" and the reason of using and incompleting rectangle formulas. Except that, there is 
incomplete to make the relation between the context and the representation of mathematical solution. However, here researcher follow up on the student's answer. The researcher interviewed that student:

$P$ : Why did you use the area?

S1: Here it has known that the length, width and place used to already sit resembles a rectangular shape (pointed at the picture) so just calculate the area of the place is used for sitting

$P$ : Yeah, for that bench, why did you also calculate the area of the seat?

S1 : Alright, because we have been already known the surface of area the boat to sit easily determine many benches by counting the area of a bench occupied. So, I just needed to divide it

$P$ : In the question, there is no information for the bench, how did you know that information?

S1: Guessing, approximately the size of the sitting position and adding the distance between the seats, so here it is estimated the length of $100 \mathrm{~cm}$ size while the width of the bench using the width of boat

$P$ : Was the length $100 \mathrm{~cm}$ ?

S1: No, it could be less than $100 \mathrm{~cm}$

$P$ : If the length is less than $100 \mathrm{~cm}$, can the bench be made more or less?

S1: More, it means could be more than ten benches

Based on the above interviews, the student understood the meaning of the problem well and gave the argument clearly. The student solve problem by using the area to find the surface area of the boat and the area of the bench to make it easier to find how many benches that can be made. Furthermore, after questioning whether the approximate length used can produce maximum bench, it turns out that the student just realize that there is a possibility that the bench will be more than ten if the length used is less than $100 \mathrm{~cm}$. From the answer and interview above, it can be concluded that the student has good reason ability so that it can determine and provide the right reasons for the problem. This is in accordance with Hapizah [25] who said that with good reason, the student can solve problem well too. In addition, from the results of answer and interview with the student can be found with good reason ability, indirectly train the student communicate ability which the student can provide a logical reason of the answer in the question. As for the incorrect student's answer as below:

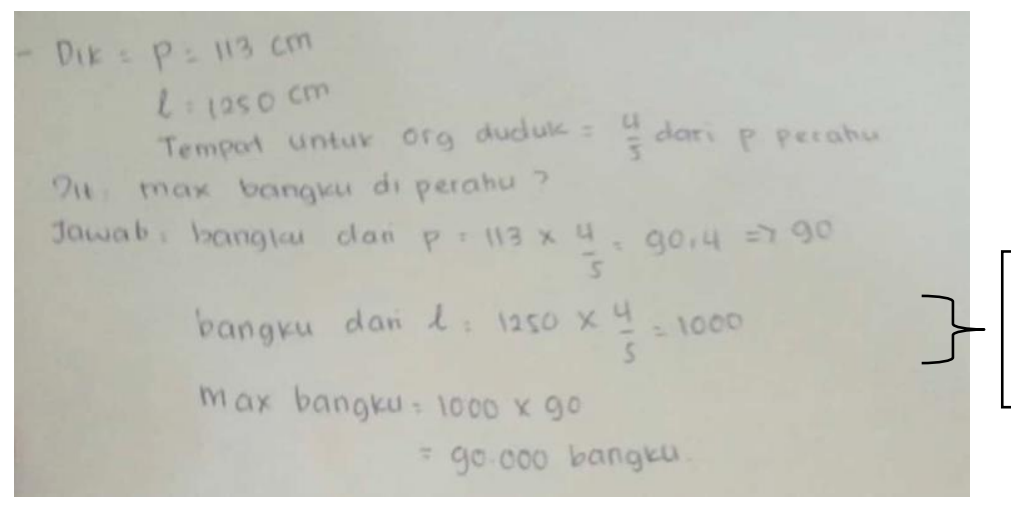

The student errors in communicating context explanations problem

Figure 4. Incorrect student's answer

For student answer as shown in Figure 4, the student has already understood the meaning of the given problem by writing what she has known from the problem. However, the student can not understand the meaning of the problem well because from the answer above, both the length and width of the boat are multiplied by $\frac{4}{5}$ whereas only the length section is multiplied by $\frac{4}{5}$. In addition, for calculating the maximum number of bench, the student need to calculate the area of the boat by multiplying the length and width that is known so the answer that is obtained not logical. The researcher interviewed that student:

$P:$ Is it true that the length and width mutltipled by $\frac{4}{5}$ ?

S2: Yes

$P$ : Is the information above asked to multiply by $\frac{4}{5}$ ? 


\section{S2: Oh yeah, only for the length \\ $P$ : So, how about count maximum bench? why is it directly multiplied like this? S2: (silent)}

Based on the student answer above, the student needs encouragement to solve existing problem because the student doesnt have a detail clue in understanding of the mean problem. After being interviewed, the student just realized that the part of the boat is only for its length. According to Pugalee's opinion [26] which said that if the student is given the opportunity to communicate about mathematics, the student will seek to improve her skills and thoughts process in developing mathematical literacy ability. Therefore, the result that is obtained is the student should be asked feedback the mean and purpose of the answer given.

From the field test results were obtained that only two of 32 students can solve the problem by estimating the answer with the right reasons (full credit). Only six from seven ability appears in this problem. The ability of using mathematics tool is not appear. The result of the analysis shows that only 4 students get partial credit and 2 student get full credit in students' ability in representating solution and reasoning. This shows that students understand the context used so as to represent problems and guess the answers to be generated. However, this can be seen clearly when students are interviewed because students' written communication ability are still low, only 7 students get a partial credit. While no student get full credit because the students are not used to write step-by-step explanations to find solutions but just write down the problem given. Referring to the problems that have been developed, to elicit good student communication skills can be supported by improving questions from questions such as "explain in detail the answers you can". It aims to make it easier for readers to read student answers without interviewing the students. While the mathematical ability of the students in determining the limitations of mathematical solutions is only 4 students get partial credit because students only write an answer without try to find another answers so that no student is able to make an explanation to support or deny the limitations of the solution. The causes of mathematical literacy capability are in accordance with Mahdiansyah's research findings [28] that students only answer the problem without providing clear explanations and steps of workmanship. In fact, the ability of mathematical literacy is needed. This is in accordance with the literacy process that the students not only have the ability to calculate but also the ability needed how to communicate, reasoning and other mathematical thinking processes [7].

The low mathematical literacy ability of the students' is due to the unfamiliarity of students working on non-routine problem related to the context and the ability of mathematical literacy in the solution. The students are only used to do routine problem that focus on finding a solution regardless of the process solution found. In addition, there are students who consider less information from the problem. It is according to the low PISA Indonesia students results [3]. Therefore, the need for special attention to train Indonesian students to get used to do PISA problems in a way to make learning more meaningful by using the students solve the problem of PISA. PISA problem can not only be given in learning in the classroom but also can be used as a homework. The student are used to focus in thinking rather than looking for the final answer. This opinion is in accordance with [27] which is said that the main goal of learning is not to get an answer but to emphasize how the progress to analyze the question in order to get the answer.

\section{CONCLUSION}

Based on the problem development process, problem has generated a valid, practic and had a potential effect. Valid is assessed from the comment and suggestion by expert reviews and one to one stage that the suitability of the problems developed with the framework PISA that was connected problems with daily life, used a rowing boat at Asian Games 2018 as the context and used space and shape as the content. Practic seen from the students' ability to understand the problems that have been developed in the small group stage. Potential effects seen from the analyzed from the results of student answers and interviews raises mathematical ability.

From developed problems raises basic mathematical ability such as the ability to communicate explanations from the context, apply strategy, define the boundary of mathematical solution, interpret mathematical result, reflect mathematical solution, and connect between the contexts of a problem with the obtaining solution. However, the results of the field tests indicate that students' mathematical literacy ability are still low, especially in determining solution boundaries, explanations for denying the solution and linking the problem context with the obtaining solution. In addition, from the results of answers and interviews with the students it can be found that with good reason ability indirectly to train the students communicate ability where the students can provide a logical reason from the answers.

Based on the result and conclusion of the research, it is suggested that the student should use PISA like problem with branches Asian Games 2018 which have been developed according to the educational 
material, for train student's mathematics literacy ability or as alternative's way in improving various problem given to students. In addition, the students are used to do PISA like problems to train the ability of mathematical literacy.

\section{ACKNOWLEDGEMENTS}

Thank you to Ross Turner, Kaye Stacey, and Ahmad Fauzan as a validator who have spared their time for validate my instrumient. Headmaster and teacher in SMA N 10 Palembang who gave me the chance to do a research in that school. Nonetheless, student in one to one, small group, and field test that is involved in my research.

\section{REFERENCES}

[1] Kemendikbud, "Salinan Lampiran Peraturan Menteri Pendidikan dan Kebudayaan Nomor 69 Tahun 2013 Tentang Kerangka Dasar dan Struktur Kurikulum Sekolah Menengah Atas/Madrasah Aliyah,”Jakarta, 2013.

[2] R. Johar,"Domain PISA untuk Literasi Matematika," Jurnal Peluang, vol. 1, no. 1, pp. 30-41, 2012.

[3] OECD, "PISA 2018 Draft Analytical Framework," Paris: OECD, 2016.

[4] A. Sturgeon, "Why Literacy Should be Included in an Effective Elementary Math Curriculum," EURASIA journal of Mathematics, Science adn Technology Education, vol. 14, no. 2, pp. 557-560, 2018.

[5] OECD, "Assesment and Analitycal Framework," Paris: OECD, 2015.

[6] M. S. Jane, "Developing Geometric Reasoning," Washington DC: GED Mathematics Training Institute, 2006.

[7] OECD, "PISA 2012 Results: What Students Know and Can Do- Student Performance in Mathematics, Reading and Science," Paris: OECD, 2014.

[8] I. F. Nurani, E. B. Irawan, \& C. Sa'dijah, "Level berpikir teori Van Hielle berdasarkan gender pada siswa kelas VII SMP ISLAM Hasanudin,” Jurnal Pendidikan: Teori, Penelitian, dan Pengembangan, vol. 1, no. 5, pp. 978-983, 2016.

[9] F. Nurhasanah, "Concept of Triangle: Examples of Mathematical Abstraction in Two Different Context," International Journal on Emerging Mathematics Education (IJEME), vol. 1 no. 1, pp. 53-70, 2017.

[10] K. Stacey, "The PISA View of Mathematical Literacy in Indonesia," Journal on mathematics education (IndoMS$J M E$ ), vol. 1, no. 2, pp. 95-126, 2011.

[11] S. Djahuno, "Pengembangan Soal-soal Open- Ended pada Pokok Bahasan Barisan dan Deret Bilangan di Kelas IXA SMP Negeri 2 Talitoli, Jurnal Kreatif Tadulako, vol. 4, no. 6, 2016.

[12] A. Wijaya, "Difficulties in Solving Context-Based (PISA) (online)," Diakses dari http://eprints.uny.ac.id/24176/1/E-3.pdf., 2014.

[13] T.P.M. Sasongko, "Pengembangan Paket Soal Model PISA konten Space and Shape untuk Mengetahui Literasi Matematika Siswa SMP,” Jurnal Edukasi, vol. III, no.1, pp. 27-32, 2016.

[14] R.I.I. Putri,"Evaluasi Program Pelatihan Pendidikan Matematika Realistik Indonesia (PMRI) Bagi Guru Matematika Sumatera Selatan,” Seminar Nasional Implementasi Kurikulum 2013, 2013.

[15] A.R. Gatabi, K. Stacey, \& Z. Gooya, "Investigating Grade Nine Textbook Problem for Characterisctics Related to Mathematical Literacy, " Mathematics Education Research journal, pp. 403-421. Doi 10.1007/s12294-012-00520$5,2012$.

[16] Act no.20 of 2003, “UUD RI No 20 Tahun 2003 tentang Sistem Pendidikan Nasional,” Jakarta, 2003.

[17] Y. Y. Putra, "Pengembangan soal matematika model PISA level 4, 5, 6 menggunakan konteks lampung," Jurnal matematika kreatif-inovatif kreano, vol. 7, no. 1, 2016.

[18] K. Barezi, K, "A Study on How Hungarian Students Solve Problems that are Unusual for them," Handbook on Mathematics Teaching Improvement: Professional Practices that address PISA, 2008.

[19] Zulkardi, "PISA, KTSP and UN," In prosiding KNM XV: IndoMS dan jurusan matematika UNIMA Manado, pp. 53-54, 2010

[20] H.F. Jameel, "Causes of Poor Performance in Mathematics from the Perspective of Students, Teachers, and Parents," American Scientific Research Journal for Engineering, Technology, and Sciences (ASRJETS), vol. 15, no. 1, pp. 122-136, 2016.

[21] Sumselpostonline,"Ciptakan Pembelajaran Matematika dengan Asean Games. Online: http://sumselpostonline.com/ciptakan-pembelajaran-matematika-dengan-asean-games/, 2015.

[22] M. Tessemer, "Planning and conducting formative evaluations: improving the quality of education and training," Philadelphia: Kogan page, 1993.

[23] Zulkardi, "Developing a learning environtment on realistic mahematics educaion for indonesian student teachers," $\mathrm{Ph} . \mathrm{D}$. Thesis University of Twente, Enschede, the Netherland, 2002.

[24] R. Bairac, "Some Methods for Composing Mathematical Problems," International Journal for Mathematics Teaching and Learning, Retrieved from: http://cimt.plymouth.ac.uk/journal/bairac.pdf , 2005.

[25] Hapizah, "Pengembangan Instrumen Kemampuan Penalaran Matematis Mahasiswa pada Mata Kuliah Persamaan Diferensial," Jurnal Kreano, vol. 5, no. 1, ISSN: 2086-2334, 2014.

[26] D. A. Pugalee, "Using Communication to Develop Student's Literacy," Journal research of mathematics education, vol. 6, no. 5, pp. 296-299, 2001. 
[27] B. Yustriningrum, "Meningkatkan Hasil Belajar Siswa pada Konsep Bangun Ruang melalui Cooperatif Learning berbasis Open Ended berbantuan Alat Peraga Kelas V SD," Edumatica, vol. 7, no. 1, issue 2088-2157, 2017.

[28] Mahdiansyah \& Rahmawati, "Literasi Matematika Siswa jenjang Pendidikan Menengah: Analisis Mengunakan Desain Tes Internasional dengan Konteks Indonesia", Jurnal pendidikan dan kebudayaan, vol. 20, no. 1, 2014.

\section{BIOGRAPHIES OF AUTHORS}

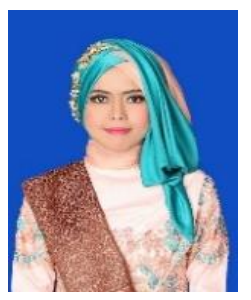

Arvin Efriani is a student in magister of mathematic education at Sriwijaya Univesity. She was born in Palembang, April, 19 ${ }^{\text {th }}$ 1994. She graduated from mathematics education bachelor degree at UNSRI in 2016.

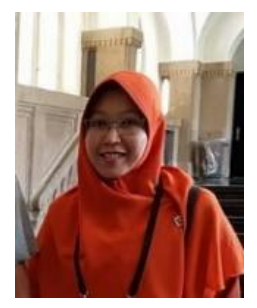

Prof. Dr. Ratu Ilma Indra Putri, M.Si is a lecturer in mathematics education at Sriwijaya University. She was born in Palembang, August, $14^{\text {th }} 1969$. She graduated from mathematics education bachelor degree at UNSRI in 1992. Statictic, got master degree at IPB in 1999. Research and Evaluation education, got doctor degree at UNJ in 2010 .

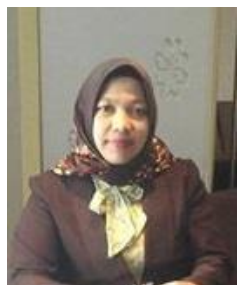

Dr. Hapizah, M.T. is a lecturer in mathematics education at Sriwijaya University. She was born in Tebing Gerinting, May, 30 ${ }^{\text {th }}$ 1979. She graduated from mathematics education bachelor degree at UNSRI in 2001. Informatica, got master degree at ITB in 2008. Mathematics education, got doctor degree at UPI in 2015. 